\title{
The Last auto-da-fé in Europe? The Case of the Jewish Merchant Boroch Leibov and Captain-Lieutenant Aleksander Voznitsyn and Its Consequences*
}

\begin{abstract}
An unprecedented event took place in the Russian Empire in the second half of 1738. On the main square of St. Petersburg, a Jewish merchant, Boroch Leibov, and a Russian navy captain-lieutenant, Aleksander Voznitsyn, were burned alive at the stake. Voznitsyn had met Leibov while staying in Moscow. Impressed by the teachings of his new acquaintance, he decided to convert to Judaism. The reason for this decision was probably the mental illness of the captain or his unconfirmed family ties with the fifteenth-century Heresy of the Judaizers. Based on the Sobornoye Ulozheniye decree, both of them were sentenced to public burning for withdrawal from the Orthodox faith and blasphemy, in the case of Voznitsyn, and for persuading an Orthodox man to withdraw from his faith, in the case of Leibov. The trial of Boroch and Voznitsyn was widely reported in the whole Russian Empire and became the cause of rapid changes in the policy toward the Jews. Both Empress Anna Ivanovna and, after 1740, her successor, Elizabeth Petrovna, signed a number of decrees ordering the Jews to leave the borders of the Russian Empire.
\end{abstract}

Keywords: trial, burn, Russian Empire, Judaism.

* Polish edition: Maciej Szkółka, "Ostatnie auto da fé w Europie? Sprawa Żyda Borocha Lejbowa i kapitana-lejtnanta Aleksandra Woznicyna oraz jej konsekwencje," Studia Judaica 19 (2016), 2: 301-316.

The special edition of the journal Studia Judaica, containing the English translation of the best papers published in 2016, was financed from the sources of the Ministry of Science and Higher Education for promotion of scientific research, according to the agreement 508/P-DUN/2016. 
In the second half of 1738, an unprecedented event took place in the Russian Empire involving a representative of the Jewish community. On the main square in St. Petersburg, a man named Boroch Leibov and a captain-lieutenant ${ }^{1}$ of the Russian navy named Aleksander Voznitsyn were burned alive at the stake.

Extensive information on this event is lacking in Polish works on the history of the Jewish community in the Russian Empire. Even Aleksander Solzhenitsyn's book, Dvesti let vmeste [Two Hundred Years Together], ${ }^{2}$ contains no mention of it. Furthermore, in Antony Polonsky's monumental work on the history of Jews in Poland and Russia, the entire incident was reduced to just one sentence. What happened to Voznitsyn and Boroch was neither analyzed there, nor placed in a greater context. The reader only learns that in 1738 , a Russian navy officer who had converted to Judaism and the Jew responsible for converting him were burned in St. Petersburg for their infractions. ${ }^{3}$

Significantly more information can be found in the Polnoye Sobraniye Zakonov Rossiiskoy Imperii [Complete Collection of the Laws of the Russian Empire]. ${ }^{4}$ Among decrees regulating the status of the Jewish population in the Russian Empire in the eighteenth century, there is one that extensively details the abandonment of Orthodoxy and transition to Judaism, a process that culminated in the burning of Boroch Leibov and Aleksander Voznitsyn at the stake. ${ }^{5}$

Such a turn of events may seem natural. Boroch persuaded Voznitsyn to abandon the Orthodox Church, after which he became circumcised, and blasphemed Jesus Christ and the Christian faith. ${ }^{6}$ Yet after analyzing other sources and works concerning this event (primarily in Russian), it became clear that the matter was likely more complicated than it might have originally seemed. Indeed, many unanswered questions arose. Why was Voznitsyn persuaded to convert to Judaism? Is it possible that the initiative came directly from him? Was this the only such case in eighteenth-century

${ }^{1}$ Ranked ninth in the Table of Mariners' Rankings from the reign of Empress Anna Ivanovna Romanova (1730-1740). This corresponds to the rank of captain today.

2 Aleksander Solzhenitsyn, Dvesti let vmeste: 1795-1995. Chast' pervaya: V dorevolyutsionnoy Rossii (Moscow, 2001).

3 Antony Polonsky, The Jews in Poland and Russia, vol. 1: 1350-1881 (Oxford-Portland, 2010), 325.

${ }^{4}$ Polnoye Sobraniye Zakonov Rossiiskoy Imperii, 1st edition, vols. 1-45: 1649-1825, ed. Mikhail Mikhailovich Speransky (St. Petersburg, 1830) [henceforth: PSZRI (1)].

${ }_{5}^{5}$ Ukase 7612, in PSZRI (1), vol. 10: 1737-1739, p. 556.

${ }^{6}$ Ibid., pp. 556-560. 
Russia, given that it was extensively described in the Polnoye Sobraniye Zakonov? Did it require special attention? And finally, did the event have definite consequences for the entire Jewish Diaspora in Russia? Finding the answers to these questions requires approximation of the event itself, its consequences, and - as is necessary for a wider perspective - the main actors involved.

Boroch is first mentioned in a decree from 14 March 1727, which documents his expulsion together with another Jew, also named Leibov, from the borders of the Empire. It is highly probable that the Leibov mentioned here was the father of Boroch, for in later sources Boroch appears as Boroch Leibov, and the tradition at that time was for Jews to take their father's given name as their last name. Based on this decree, we also know that Boroch and his father lived in Zwierowicze, ${ }^{7}$ a village in the Smolensk region, where they leased customs and inn taxes. Yet the decree made no mention of the reasons for their expulsion. ${ }^{8}$ More revealing is a decree from 3 July 1738, which provides specific information on Boroch and Voznitsyn. It indicates that Boroch, aside from persuading Voznitsyn to convert to Judaism, was also involved in other offenses and crimes within the Smolensk region. The accusations included inciting conversion of simple people to Judaism, lawlessly building a synagogue opposite a church (in the original, the term "school" was used), killing a priest named Avra'am in Zwierowicze, and abusing a female Christian servant of his. ${ }^{9}$

It is highly likely that these accusations are the reason for his expulsion from Russia. However, they were only mentioned in reference to his 1738 trial, without any placement in time. This assumption is further enforced by a reference to interrogations from 1723, during which the townspeople and peasants allegedly reported Boroch's misdeeds. The accusations were never confirmed, and he was not proven guilty. Anna Ivanovna herself stated that there was no need for an in-depth investigation of the events given that Boroch would be sentenced to death anyway for the conversion of Voznitsyn to Judaism. ${ }^{10}$

7 Village in the Smolensk region. As of 2007, it has 127 inhabitants and is located in the Smolensk Oblast' of the Russian Federation.

${ }^{8}$ Ukase 5032, in PSZRI (1), vol. 7: 1723-1727, p. 758.

9 Simon Dubnov, "Anna Ioannovna," in Evreiskaya entsiklopediya [The Jewish Encyclopedia] (St. Petersburg, 1911), 8: 593-594.

${ }_{10}$ Ukase 7612, in PSZRI (1), vol. 10, pp. 556-557. 
The case record also mentions a few other people of Jewish origin: Szmerl (Boroch's son-in-law); Mayor from Dubrowna ${ }^{11}$ (Boroch's son), in whose home Voznitsyn accepted Judaism and was circumcised; and three other Jews, who together with Boroch persuaded him to accept the "Jewish faith." Among the latter is a man mentioned only as Fajwist, "who [was apparently] sent by Rabbis, i.e. Jewish judges, and blessed to circumcise Jewish-born youth." In other words, he was a mohel, invited specially to circumcise Voznitsyn. During the trial of Boroch and Voznitsyn, Szmerl was acquitted because his direct involvement in Voznitsyn's conversion could not be proven. The remaining Jews were not tried, as they were inhabitants of Dubrowna, which was in the Polish-Lithuanian Commonwealth and thus outside the jurisdiction of the Russian Empire. ${ }^{12}$

Aside from Boroch, Aleksander Voznitsyn was also sentenced to be burned. He was well-educated and came from an old noble family associated with Novgorod. His uncle, Prokofiey Bogdanovich Voznitsyn, was a senior member of the Moscow aristocracy and well-known diplomat whose achievements included the conclusion of a truce between Russia and Turkey in Bakhchysarai in $1681 .{ }^{13}$ Additionally, his aunt married the rear admiral ${ }^{14}$ of the Russian navy, Ivan Akimovich Sinyavin, which opened the door for Aleksander to a navy career. ${ }^{15}$

However, Voznitsyn turned out to be mentally ill, and much of his behavior baffled and annoyed the people who were close to him. For example, he squandered the majority of his estate for no particular reason. Consequently, in 1737, his sister submitted a request to the Governing Senate ${ }^{16}$ that the entire estate be transferred to her on account of her brother's insanity. After conducting the necessary investigations, the Senate confirmed that the captain-lieutenant exhibited symptoms of mental illness, and honored his sister's request, granting her power over

11 The town was located in the Grand Duchy of Lithuania until 1772, at which point it became part of the Russian Empire. As of 2015, it has 7,345 inhabitants and is located in the Vitebsk region of Belarus.

${ }^{12}$ Ukase 7612, in PSZRI (1), vol. 10, pp. 556-557.

13 The twenty-year truce ending the Russo-Turkish war, signed 13 January 1681 in Bakhchysarai in the Crimean Peninsula.

${ }^{14}$ The fourth in the Table of Mariners' Rankings starting from 1798. During the reign of Anna Ivanovna, its equivalent was shautbenakht.

${ }_{15}$ Savely Dudakov, Paradoksy i prichudy filosemitizma i antisemitizma v Rossii (Moscow, 2000), 11-12.

${ }^{16}$ Body with administrative and judicial powers created in 1711 by Tsar Peter I in place of the Boyarskaya Duma. 
the majority of the estate, and forcing Voznitsyn to take early retirement. The situation was compounded by problems with his wife, Elena Ivanovna, who- - like many of those around Aleksander—did not like him. On hearing the news of his illness and the transfer of his estate to his sister instead of her, she began to hate him. ${ }^{17}$

It was under such circumstances that Voznitsyn met Boroch Leibov in 1738 when staying in Moscow. Together, they began to read and interpret the Bible (Voznitsyn the Orthodox version, and Boroch the Jewish version). Impressed by the insights and views of his new friend, Voznitsyn decided that he wanted to convert to Judaism, recognizing Jewish law as the only correct and valid law. For this purpose, they travelled together to Dubrowna in the Commonwealth, where at the home of Jew Mayor he denied Orthodox Christianity, was circumcised, and-as he confessed during the investigation - openly blasphemed Christ, Mary, and the Christian faith. ${ }^{18}$

The whole incident may not have come to light had it not been for Aleksander's wife. After she found out what her husband had done, she, along with two witnesses, in an effort to seek revenge on him for squandering part of his estate and transferring the remainder to his sister, reported his conversion to the Synod Chancery ${ }^{19}$ in Moscow. From that point on, the entire matter started to accelerate. Voznitsyn was then called to the Synod Chancery for interrogation (initially together with Szmerl). They did not admit guilt at this phase, and the case was transferred to the Office of Secret Investigations. ${ }^{20}$ It was there that Voznitsyn was tortured, after which he admitted to accepting Judaism, and revealed Boroch Leibov as the person who tempted him into doing so and proposed the trip to the Commonwealth to finalize it. Leibov, also under the influence of torture, confessed his guilt and admitted that he had attempted to hide the fact that Voznitsyn had been circumcised during the beginning phase of the investigation. ${ }^{21}$

Despite the fact that Voznitsyn admitted guilt, cleansed his soul, and swore an oath that he would never again practice Judaism, his case was

${ }^{17}$ S. Zakusillo, "Aleksandr Artemevich Voznitsyn," in Sbornik biografiy kavalergardov, vol. 1: 1724-1762, ed. Sergey Panchulidzev (St. Petersburg, 1901), 165-167.

${ }_{18}$ Ukase 7612, in PSZRI (1), vol. 10, pp. 557-558.

${ }_{19}$ Primary administrative authority for religious crimes.

${ }^{20}$ Investigatory authority for political crimes, established in 1731 in place of the Secret Office, which was liquidated in 1726. During the reign of Catherine the Great, it was replaced by the Secret Expedition.

${ }^{21}$ Zakusillo, "Aleksandr Artemevich Voznitsyn," 166. 
referred in 1738 to a higher authority in the hierarchy of the tsarist administration: the Governing Senate's Collegium of Justice. At this point, both suspects should have been subject to further interrogations and torture in order to reveal the truth, as it still remained unclear whether or not Voznitsyn's was the only such case of conversion to Judaism, or if other third parties were involved in the affair. Without this information, it was theoretically impossible to make the final judgement. However, a direct intervention was made by Empress Anna Ivanovna herself. On her direct order from 28 May 1738, further investigations were abandoned despite objection from the Collegium of Justice. ${ }^{22}$

Both criminals were sentenced unequivocally to public burningBoroch on the basis of Chapter 22 Point 24 of the Sobornoye Ulozheniye ${ }^{23}$ (Russian legal code), which clearly prescribed punishment by death to any infidel who in any way persuaded an Orthodox Christian to abandon their faith and become circumcised ${ }^{24}$; and Voznitsyn on the basis of Chapter 1 Point 1 , which prescribed death by burning for anyone who blasphemed against Christianity and the Holy Church. ${ }^{25}$ Interestingly, after Voznitsyn's death, his wife received an appropriate portion of his moveable and immoveable property, as well as " 100 servants together with their land and other property," for her accurate reporting. ${ }^{26}$

The tragic culmination of these events was about more than just the individual departure of a Christian from his religion under the influence of a cunning Jew. For a better understanding, we must refer to the abovecited work from Russian historian Savely Dudakov, Paradoksy i prichudy filosemitizma i antisemitizma v Rossii [Paradoxes and Caprices of Philosemitism and Antisemitism in Russia]. He clearly emphasized therein that the trial of the two alleged criminals was carried out at an accelerated pace, was not completed, and resulted in a very severe punishment. For some reason, Empress Anna Ivanovna did not want it to drag on, and perhaps did not want certain facts to come to light. ${ }^{27}$

${ }^{22}$ Ibid.

${ }^{23}$ Collection of laws in the Russian Federation adopted in 1649 during the reign of Tsar Aleksey Mikhailovich.

${ }^{24}$ Ulozheniye, Chapter 22, Point 24, in PSZRI (1), vol. 1: 1649-1675, p. 156.

${ }_{25}$ Ibid., Chapter 1, Point 1, p. 3.

${ }_{26}$ Zakusillo, "Aleksandr Artemevich Voznitsyn," 166-167.

27 Dudakov, Paradoksy i prichudy, 11-12. 
Here we should recall a seemingly unimportant fact from the life of Aleksander Voznitsyn: he and his entire family were from Novgorod. From the viewpoint of a historian of Jews in Russia, this city is extremely important. At the end of the fifteenth century, the concept of the Heresy of the Judaizers was developed there, which was embraced by clergy members of various rank, as well as the city's aristocracy, and was even supported by powerful actors in the tsar's own court. The concept was eventually quelled in 1504 . However, some historians hold that a small group of followers managed to remain in hiding until the seventeenth century $^{28}$ (and possibly even as late as the eighteenth century). Savely Dudakov conjectures that the eventuality of its return drove Empress Anna Ivanovna to order a quick and brutal ending to the investigation. This can be compared to the case of the Marranos in Iberia, who for centuries cultivated the religion of their ancestors in hiding, and later revived it repeatedly under conducive conditions. ${ }^{29}$

There is no concrete evidence that the family of captain-lieutenant Aleksander Voznitsyn had any ties to the Heresy of the Judaizers, or that he wanted to cultivate the supposed tradition of his ancestors in converting to Judaism. Nevertheless, we can assume that the mentally-ill Voznitsyn persuaded himself that his ancestors were somehow connected to the Judaism-oriented sect, and was thus encouraged by Boroch to convert. Russian philosopher Vladimir Solovyov had no doubts with regard to his origin and motives, stating that the case was the last manifestation of the Inquisition in Europe, a unique auto-da-fé, the last religious burning on the Old Continent. ${ }^{30}$

Regardless, the fact remains that for Anna Ivanovna, as well as the ruling elites of the Russian Empire, the case of Boroch and Voznitsyn unambiguously represented a potential return of the Heresy of the Judaizers. As with sixteenth- and seventeenth-century Moscovian rulers, this evoked a defensive reaction among Russian elites, and aroused fear of an influx of Jews into the country, as well as a deep-seated Judeophobia. ${ }^{31}$ The effect was a drastic turn of the Empire's politics towards Jews. Anna Ivanovna's reign foreshadowed a certain "thaw" with respect to Jews and their presence in the Russian Empire. As early as 1728, a decree

${ }^{28}$ Vladislav Masalsky, "Zhidovstvuyushchie," in Entsiklopedicheskiy slovar (St. Petersburg, 1894), 11A: 943-944.

${ }^{29}$ Dudakov, Paradoksy i prichudy, 12.

${ }^{30}$ Ibid., 13.

31 Dubnov, "Anna Ioannovna," 593. 
issued by her predecessor, Peter II, allowed Jewish merchants to freely enter Little Russia for trade markets and other commercial purposes, provided they sold their goods wholesale, and did not settle there..$^{32}$ Further decrees issued under the rule of Ivanovna expanded this limited freedom. In 1731, an ukase of the Governing Senate expanded the area of temporary residence for Jews to Smolensk. Then in 1734, a personal decree from the empress expanded the commercial zone for Jewish merchants to Sloboda Ukraine (i.e. the territory to the northeast of the Poltava). A formal ban on permanent settlement within the borders of the Empire was upheld, but it appears that the authorities turned a blind eye to it. ${ }^{33}$

There was a radical change in the policy towards Jews after 1738, as if Boroch and Voznitsyn's trial breathed new life into Judeophobia in Russia. The second half of Anna Ivanovna's reign (until her death in 1740) was marked by decrees of clearly antisemitic nature. On 11 July 1740, a regulation was issued ordering expulsion of all Jews outside the borders of Russia, and forbidding them from entering for any purpose. Attached to the regulation was also a list of all Jews and their specific locations within Little Russia, totaling $573 .{ }^{34}$

Similar decrees were issued during the reign of the next empress, Elizabeth Petrovna. Her ruling from 1742 ordered all Jews, regardless of their sex, to be exiled together with all their possessions from Little and Great Russia, unless they decided to accept Orthodox Christianity. ${ }^{35}$ Then in 1744, the empress overruled the objections of some circles of Russian merchants interested in allowing Jews to conduct trade in the western provinces of the Empire. Furthermore, on 25 January of that same year, the Governing Senate adopted a decree "On the expulsion of Jews from Little and White Russia and the remaining conquered cities, and the ban of their presence in Russia, even for commercial purposes. ${ }^{136}$ This was the last ukase concerning Jews issued before the accession of Catherine II to the throne in 1762 .

The trial of Boroch and Voznitsyn was therefore not a minor event in the history of the Jewish Diaspora in Russia. It entailed significant consequences for Jews, leading the rulers of the Russian state to adopt a much tougher policy towards them. Indeed, the regulations ordering

${ }^{32}$ Ukase 5324, Point 14, in PSZRI (1), vol. 8: 1728-1732, p. 80.

${ }^{33}$ Ukase 5852, in PSZRI (1), vol. 8, p. 545; Solzhenitsyn, Dvesti let vmeste, 22.

${ }^{34}$ Ukase 8169, in PSZRI (1), vol. 11: 1740-1743, pp. 183-185.

${ }_{35}$ Ukase 8840, in PSZRI (1), vol. 11, p. 981.

36 Ukase 8867, in PSZRI (1), vol. 12: 1744-1748, p. 21. 
the removal of Jews from the country at that time were actually implemented, as opposed to the decrees issued before 1738. For example, in 1743, 142 followers of Judaism (both men and women) were expelled from Little Russia alone. ${ }^{37}$

The case of Boroch and Voznitsyn was without a doubt religiously charged, and in a certain sense, as Vladimir Solovyov wrote, the last auto-da-fé in Europe. Not only did the event reverberate throughout the Russian Empire in the eighteenth century, but it long remained in the consciousness of the Russian people, and to a certain extent became embedded in Russian culture. Just a few years after the burning, the 1738 event was referred to by poet Antiokh Kantemir; and in the twentieth century, Leontiy Josifovich Rakovsky used it as the basis of a historical novel entitled Izumlenny kapitan [Intoxicated Captain]. ${ }^{38}$

\section{Source Annex}

\section{Ukase 7612 of 3 July 1738. The highest resolution of the Senate.}

On the burning of navy captain-lieutenant Voznitsyn for departing from the Christian faith, and Jew Boroch for converting the captain to the Jewish faith.

Report. On 20 April 1738, pursuant to the ukase of Your Imperial Majesty issued on 18 April 1738, as instructed by the Office of Secret Investigations, captain-lieutenant of the Russian navy Aleksander Voznitsyn, Jew Boroch Leibov, and the son-in-law of Boroch, Jew Szmerl, as well as a credible investigation of the conversion of Voznitsyn from Orthodox Christianity to Judaism and of the blasphemous words of Voznitsyn, were sent to the Senate for consideration. Pursuant to this ukase issued in the name of Your Imperial Majesty, they shall be processed according to binding laws and ukases.

And on 21 April, on the basis of the Senate's resolution, Voznitsyn and Boroch Leibov, along with his son-in-law Szmerl, with authentic proceedings thereagainst, were sent to the Collegium of Justice, and having considered and investigated the matter according to the laws and ukases, the Collegium was ordered to sign a dictum, and submit it to the Senate for approbation.

\footnotetext{
37 Ukase 8840, in PSZRI (1), vol. 11, p. 981.

38 Dudakov, Paradoksy i prichudy, 13.
} 
On 27 April, on the basis of a resolution from the Senate, the authentic case on the murder by Jew Boroch of priest Avra'am from Zwierowicze in the Smolensk region and on other transgressions was sent from the Office of Secret Investigations to the Collegium, which was ordered to immediately check whether the case required further investigation, and after having signed the dictum, to immediately submit it to the Senate together with the dictum on the conversion of Voznitsyn to Judaism.

On 2 May, the Collegium reported to the Senate: Voznitsyn and Jew Boroch - with regard to the first case, on the circumcision and conversion of Voznitsyn to the Jewish faith and on his blasphemous words, as well as the second case, on the murder by Jew Boroch Leibov of the priest, the conversion with other Jews in Smolensk of a simple nation [to the Jewish faith], the building of a Jewish school for them, and the abuse of the Russian peasant-servant girl-pursuant to the Ulozheniye, and for the purpose of establishing the highest truth, must be firmly interrogated, and without such interrogations, the Collegium may not sign any dictum.

And on 10 May, General and Chevalier Ushakov announced in the Senate that Your Imperial Majesty has judged that Boroch should be interrogated; however, so that there is no significant delay in the processing of Voznitsyn's case resulting from varied testimonies due to inability of the suspects to withstand heavy interrogation, a sentence must be given which is legally appropriate for the conversion of Voznitsyn [to the Jewish faith] without interrogating Boroch.

Accordingly, on the basis of the Senate resolution of 16 May and the ukase submitted to the Collegium of Justice, the Collegium was ordered to sign a dictum and submit it to the Senate for approbation, without the interrogation of Jew Boroch Leibov, Voznitsyn, or Jew Szmerl that they deserve pursuant to the law.

On the basis of the investigation and the court, the Collegium presents the following: ${ }^{39}$

1. Voznitsyn shall be subject to death by burning for the reason that, in the Office of Secret Investigations, after taking him on 22 March to the torture room, Voznitsyn pleaded guilty and confessed that he accepted the Jewish faith and wanted to be circumcised. Voznitsyn, who was educated in such matters by Jew Boroch, agreed to go with Boroch from Moscow to Poland for the purpose of being circumcised and becoming more familiar

${ }^{39}$ In the original, points $1,2,3$, and 4 were written without paragraphs. 
with the Jewish faith. He stayed in Dubrowna at the home of Boroch's son, Jew Mayor, to which Boroch brought three other Jews, whose names he does not remember. After many teachings and persuasions by these Jews, Voznitsyn accepted the circumcision, which was performed by one of these Jews brought by Boroch. Present all along were Boroch and his son Mayor, and after the circumcision, the other Jews together with Boroch and his son, in accordance with the Jewish ritual, had dinner, and Voznitsyn fell ill from the circumcision and laid in his bed; and Voznitsyn, without any intention by way of his simplicity, declaimed the Jewish Sabbaths and blasphemous words against Jesus Christ Our Lord that were testified to in detail by the townspeople; and after instruction from the three above-mentioned Jews brought by Boroch for circumcision, Voznitsyn no longer recognized Jesus Christ as the real God; and after being put on the wheel, Voznitsyn spoke about the above-mentioned with repentance, as he did before; and at first, Voznitsyn denied his guilt, believing that no one would find out about it, as he feared great torment; but today, with regard to the above-mentioned, he declares his guilt, thus cleansing his soul, and that in the future he will not keep the [Jewish] faith or rituals. In this way, Voznitsyn's conscious and desirous conversion from Orthodox Christianity to Judaism after being instructed by Jews, his circumcision, and his utterance of blasphemous words were clearly revealed. According to the Ulozheniye, Chapter 1, Point 1: "If any infidel or even a Russian speaks blasphemies against Our Lord and Savior Jesus Christ, Our Most Holy Mother and Virgin Mary, the Holy Cross, or the saints, then he, the blasphemer, must be burned." Voznitsyn, after being taken from the wheel, in the Secret Office on 22 [March], during a supplementary interrogation in the torture chamber, said with repentance that Boroch brought three Jews to his son's home, one of which circumcised him, and that the Jews told him that he no longer needed to believe the new law given by Jesus. Voznitsyn, without intention, and by way of his ignorance, uttered important, blasphemous words, and declared that, after instruction from the Jews, he no longer acknowledged Jesus Christ as the real God. Voznitsyn admitted that he, hastily and in fear, confessed an untruth, and knowingly denied the charges in an effort to avoid the death penalty. Then, Jew Boroch Leibov, during an interrogation about his meeting with Voznitsyn in the Secret Office on 23 March, confessed his Jewish faith and that they had read the Bible together, Voznitsyn the Russian version, and Boroch the Jewish version, as well as the statement 
made by Voznitsyn to Boroch about his acknowledgement of Jewish law as correct, his desire to be circumcised, and other [things] written in this report. During this interrogation, Boroch declared that Voznitsyn, at the home of Boroch's son, folded his hands and swore his intention to be circumcised; and that he, Boroch, witnessing Voznitsyn's oath, called to the home of his son a Jew living in Dubrowna named Fajwist, also called Piejwisz, who [was apparently] by Rabbis, i.e. a Jewish judges, blessed with the ability to perform the circumcision of Jewish-born youth. Voznitsyn gave Fajwist 10 roubles, and requested that he perform a circumcision in accordance with Jewish law, where Boroch allowed Fajwist to do so, saying that he had nothing to fear, and that he should perform the circumcision. Then, Fajwist circumcised Voznitsyn; and Voznitsyn, not only during interrogation, but in his confession, concealed the fact that he had sworn an oath, that he had been circumcised, and that he had given Fajwist 10 roubles. Nevertheless, he was exposed by Boroch's testimony, after which his behavior cannot be justified by any of his repulsive excuses or concealment. Indeed, they indicate his blatant guilt, and he is worthy of the death penalty. And if he, Voznitsyn, did not on his own volition convert from Orthodox Christianity to Judaism or receive circumcision, but by some means was forced or cheated into doing so, then pursuant to the Ulozheniye, Chapter 22, Point 24, such cases must be sent to the Patriarch or other authority for implementation of the ukase on the basis of the Holy Apostles and the Holy Fathers; but Voznitsyn, as testified to earlier, did this on his own volition. Pursuant to this point, Voznitsyn, not having been forced or cheated, deserves to be burned. Additionally, Voznitsyn uttered important and blasphemous words against the Orthodox Church. This blasphemy alone, without his other abominable deeds, is enough that he receive the death penalty irrevocably, according to the above-mentioned Chapter 1 Point 1 of the Ulozheniye.

2. Jew Boroch Leibov is worthy of death by burning on account of the following: (during interrogation on 23 March 1738 in the Office of Secret Investigations, he confessed) that, in leading Voznitsyn to convert to Judaism from Orthodox Christianity, he met with him during a stay in Moscow to discuss Jewish law and read the Bible-Voznitsyn the Russian version, and Boroch the Jewish version-and through the persuasion and instruction of Boroch, Voznitsyn left Moscow. During the stay of Voznitsyn in Poland, and on the recommendation of Boroch, Voznitsyn swore to uphold Jewish law; and then, after the persuasion of Boroch, 
Fajwist circumcised Voznitsyn; and after the circumcision, they ate dinner with the money they had received from Voznitsyn. And in Moscow, in the Synod Chancery, Boroch denied guilt of all of the aforementioned, wanting to conceal the fact of Voznitsyn's circumcision. And in the Ulozheniye, Chapter 22, Point 24, it is ordered that: "If any pagan, by any means, including violence or trickery, forces a Russian person to accept his pagan beliefs and receive circumcision, he shall be hunted and burned." And pursuant to this point in the Ulozheniye, Boroch shall be subject to such execution, so as to once and for all discourage others from doing such things in the future; and that those who are unaware, upon seeing the execution of the subverter and instigator, tantalizing them with his devilish guile through charm and trickery under the guise of righteousness and truth, shall not turn away from Orthodox belief, which above all must be upheld.

3. With regard to Boroch Leibov's role in the murder of priest Avra'am, the conversion together with other Jews of simple people to the Jewish faith in Smolensk, the building with them of the Jewish school [synagogue], and other events reported by inhabitants of Smolensk (Gerasim Szyła and Siemion Paskin), as well as the abuse of a Christian servant girl [from] the Zwierowicze estate, village Kobylaków, reported by her, and other [things reported] by peasants from the Zwierowicze municipality and inhabitants of the village Zwierowicze, Fiskal, starostas and priests, and other townspeople during the investigation carried out in 1723 by Filofiey, the Archbishop of Smolensk and Dorogobuzh-although the matter has not yet been investigated, there is no need to do so if in the opinion of the Collegium the Jew should be given the death penalty.

4. According to the Collegium, Boroch's son-in-law, Jew Szmerl, mentioned in the above description of the case of Voznitsyn and Jew Boroch, should be freed for the reason that his role in the matter is not essential, and his consent to the conversion of Voznitsyn to the Jewish faith was neither indicated by Voznitsyn nor Jew Boroch.

According to the ukase of Your Imperial Majesty given to the Senate on 9 June [July?] 1735, none of Your Imperial Majesty's ukases, aside from those signed by the hand of Your Imperial Majesty or the hands of all of Your Imperial Majesty's Cabinet Ministers, will be accepted or put into force, and should any verbal ukases be announced, they must be reported to the Cabinet of Your Imperial Majesty. For this reason, the Senate, loyally submissive to Your Imperial Majesty, would like to report and request Supreme Imperial confirmation from Your Imperial 
Majesty on an ukase from General and Chevalier Ushakov that Jew Boroch Leibov should not be interrogated. The Senate is of the loyally submissive opinion that Jew Boroch Leibov and Voznitsyn should be interrogated in order to find out whether Boroch will identify one of his associates in the conversion of others from the pious Greek faith to the Jewish faith, or in other matters against the Eastern Orthodox Church; and if they are executed without an investigation, these guilty parties, who they are currently hiding, may remain unpunished for their transgressions, and there will be no one else to interrogate. If Your Imperial Majesty wishes to have this matter resolved without the interrogation of Boroch and Voznitsyn, then the Senate will agree with the opinion of the Collegium of Justice that Boroch and Voznitsyn, for their proven transgressions and pursuant to the above-mentioned points of the Ulozheniye, should be publicly burned; and for this, the Senate faithfully requests Your Imperial Majesty for the issuance of an ukase.

Resolution. Because they themselves confessed-Voznitsyn to blaspheming Our Lord and Savior Jesus Christ, to disrespecting the real Christian faith, and to accepting the Jewish faith, and Jew Boroch Leibov to encouraging him to convert to Judaism-there is no need to interrogate them further, so that this matter against God is not continued, and so that the blasphemer, Voznitsyn, and the Jew who converted him, Boroch, do not dare to bewitch others. That is why, for their transgressions against God, both shall be burned to death, with no further delay, pursuant to the laws of the state, so that others, in seeing the ignorance of the blasphemers, will be unable to leave the Christian faith, and that others like Jew Boroch may not tempt them away from the Christian faith with their own. And Jew Szmerl, who was uninvolved in this matter, shall be freed. 